\title{
PENGARUH SERVICE QUALITY TERHADAP REPURCHASE INTENTION MELALUI CUSTOMER SATISFACTION PADA SKIN ORIGIN KOTA PALU
}

\author{
Sofia Agata Sarapung \\ Ponirin \\ Program Studi S1 Jurusan Manajemen Fakultas Ekonomi dan Bisnis, Universitas Tadulako \\ email: sofia.agata97@gmail.com;ppaidjan@gmail.com;
}

\begin{abstract}
The aim of this study is to determine and analyze the effect of service quality variables on repurchase intention through customer satisfaction as a mediating variable. The variables of this study are service quality $(X)$, repurchase intention $(Y)$, and customer satisfaction $(Z)$. The method of this research is a descriptive causal method with the sample size of 70 respondents. The sampling technique in this research is non-probability sampling with purposive sampling technique. The method of data analysis in this research uses Partial Least Square (PLS) with the statistical program SmartPLS 3.0. The result of this study showed that: 1). Service Quality does not affect on repurchase intention at Skin Origin beauty salon in Palu City; 2). Service Quality affect significantly on customer satisfaction at Skin Origin beauty salon in Palu City; 3). Customer Satisfaction affect significantly on repurchase intention at Skin Origin beauty salon in Palu City; 4). Service quality has an indirect effect on repurchase intention, but it must go through customer satisfaction at Skin Origin beauty salon in Palu City.
\end{abstract}

Keywords: service quality, repurchase intention, customer satisfaction.

\begin{abstract}
ABSTRAK
Penelitian ini bertujuan untuk mengetahui dan menganalisis pengaruh dari variabel kualitas layanan terhadap pembelian kembali dengan melalui kepuasan pelanggan sebagai variabel mediasi. Variabel penelitian ini yaitu kualitas layanan $(\mathrm{X})$, pembelian kembali $(\mathrm{Y})$ sebagai variabel dependen, dan kepuasan pelanggan $(\mathrm{Z})$. Metode penelitian yang digunakan adalah metode deskriptif kausal dengan jumlah sampel 70 orang. Bentuk penarikan sampel menggunakan non-probability sampling dengan teknik purposive sampling. Metode analisis data yang digunakan dalam penelitian ini adalah Partial Least Square (PLS) dengan bantuan program statistic SmartPLS 3.0. Hasil penelitian dalam penelitian ini yaitu: service quality tidak mempengaruhi repurchase intention di salon kecantikan Skin Origin di Kota Palu; service quality mempengaruhi customer satisfaction di salon kecantikan Skin Origin di Kota Palu; customer satisfaction mempengaruhi repurchase intention di salon kecantikan Skin Origin di Kota Palu; dan service quality memiliki pengaruh tidak langsung terhadap repurchase intention tetapi harus melalui customer satisfaction di salon kecantikan Skin Origin di Kota Palu.
\end{abstract}

Kata Kunci: service quality, repurchase intention, customer satisfaction.

\section{PENDAHULUAN}

Di Indonesia, seperti kebanyakan negara-negara berkembang lainnya, perkembangan sektor jasa juga berlangsung sangat cepat. Hal ini menyebabkan adanya persaingan yang ketat dalam bidang penjualan jasa. Jika sebuah perusahaan tidak mampu memberikan pelayanan yang baik pada pelanggan, maka pelanggan dengan mudah akan beralih ke penyedia jasa yang lebih mampu memahami kebutuhan spesifik dari pelanggan. Beberapa tahun terakhir, jika dilihat dari perkembangan perekonomian Indonesia yang sudah semakin meningkat berdampak kepada gaya hidup masyarakat yang semakin meningkat pula dan membuat masyarakat semakin sibuk akan pekerjaannya. Schoell dan Gultinan (dalam Iin, 2013) mengatakan terdapat berbagai faktor dikemukakan sebagai pemicu pertumbuhan jasa yang demikian pesat diantaranya adalah: 1) Adanya 
peningkatan sektor jasa dalam perekonomian, 2) Presentase wanita yang masuk dalam kategori bekerja semakin banyak, 3) Tingkatan harapan hidup semakin tinggi, 4) Produk yang dibutuhkan dan dihasilkan semakin kompleks, 5) Perkembangan teknologi yang semakin cepat.

Perubahan gaya hidup membuat mobilitas masyarakat semakin tinggi, sehingga orang-orang banyak menghabiskan waktunya hanya untuk pekerjaan dan tentunya menyita waktu yang cukup banyak sehingga membuat sebagian orang lupa pentingnya perawatan untuk diri sendiri. Persaingan yang semakin ketat mengharuskan beberapa perusahaan untuk tetap menjaga keberlangsungan bisnisnya, dengan cara mempertahankan pelanggannya. Kotler \& Armstrong (2016), mengatakan bahwa strategi pemasaran adalah suatu mindset pemasaran yang digunakan dalam mencapai tujuan perusahaan dimana didalamnya terdapat strategi untuk sasaran pasar. Berhasil atau tidaknya suatu perusahaan sangat ditentukan dari strategi bisnis apa yang digunakan. Pada strategi pemasaran pihak pemasar perlu mengkaji setiap karakter perilaku pelanggan yang diterapkan kedalam harapannya sehingga dapat mengetahui alasan apa pelanggan melakukan pembelian, sehingga dapat diketahui strategi yang tepat untuk digunakan pada usaha yang dijalankan. Pihak pemasar harus mengaktualisasikan setiap harapan pelanggan menjadi suatu kepuasan atas pelayanan yang diberikan pada pelanggan. Tujuannya adalah untuk membangun hubungan kepada pelanggan dan membuat pelanggan menjadi loyal terhadap perusahaan baik masa sekarang maupun di masa mendatang.

Perusahaan yang tidak mempunyai pelanggan yang tetap, biasanya dengan mudah mengalami resiko kemunduran dalam bisnisnya karena perusahaan tersebut harus selalu mencari pelanggan yang baru setiap saat. Salah satu jenis usaha jasa yang cukup potensial dan memiliki prospek pasar yang relatif besar saat ini adalah jasa usaha salon. Saat ini, di Kota Palu telah berkembang usaha-usaha salon kecantikan. Hal ini menandakan bahwa pada industri salon kecantikan memiliki peluang usaha yang cukup besar untuk bersaing dalam memperebutkan pangsa pasar yang cukup ketat. Agar dapat bertahan bahkan menjadi unggul dalam memperebutkan pangsa pasar yang semakin ketat di zaman modern ini, maka setiap usaha salon kecantikan harus memiliki kemampuan dalam menerapkan strategi pemasaran yang cermat dan tepat. Salah satu bentuk strategi pemasaran yang dapat dikembangkan oleh setiap usaha jasa salon yaitu dengan meningkatkan kualitas layanan.

Pada bisnis salon kecantikan pelayanan kepada pelanggan harus dipandang sebagai bagian dari produk yang ditawarkan, karena ketika kita melayani konsumen dan konsumen tersebut merasa puas dengan apa yang kita kerjakan atau hasil yang kita berikan dan sesekali melakukan komunikasi pada saat pengerjaan berlangsung, maka konsumen akan merasa dilayani dengan baik dan ada peluang untuk konsumen tersebut untuk datang kembali. Salon kecantikan yang memiliki fasilitas dan pilihan perawatan yang lengkap akan membuat salon itu akan semakin banyak konsumen karena memiliki pilihan perawatan yang beragam.

Salah satu salon kecantikan yang terlengkap di Kota Palu saat ini adalah Skin Origin yang terletak di Jalan Sis Aljufri nomor 70 Palu. Salon kecantikan ini berdiri sejak tahun 2011. Berkat usaha Ibu Jean Simon Djaelangkara sebagai pemilik (owner) yang semaksimal mungkin untuk memajukan dan menghadapi berbagai kendala dan tak pernah putus asa dalam menjalankan usahanya, akhirnya Skin Origin menjadi salah satu salon kecantikan yang terbesar, terlengkap, dan ternama di Kota Palu seperti saat ini. Bentuk perhatian dari pemilik salon dalam mengembangkan kualitas layanan dari jasa yang diberikan pada pelanggan diwujudkan dengan cara memperhatikan kelengkapan sarana dan fasilitas yang dimiliki, keterampilan karyawan yang dipekerjakan, tarif yang sesuai dengan perawatan yang diberikan pada pelanggan. Jenis perawatan yang ditawarkan di Skin Origin pun bermacam-macam, contohnya mulai dari perawatan wajah, rambut, kulit, hingga perawatan kuku pun tersedia di Skin Origin.

Beberapa contoh bentuk variasi produksi jasa kecantikan yang diberikan pada salon kecantikan Skin Origin adalah sebagai berikut: Facial Deluxe Biokos, Super Facial Oxygeneo, IPL Hair Removal, Oxygen Infusion, eMatrix Sublative, HIFU, Manicure, Pedicure, dan lain-lain. Meningkatkan kualitas jasa kecantikan yang baik melalui variasi produksi jasa yang diberikan kepada pelanggan, maka Ibu Jean Simon Djaelangkara sebagai owner (pemilik) dari salon kecantikan Skin Origin mengharapkan dapat memberikan value (nilai) superior kepada pelanggan, sehingga reputasi salon semakin positif dimata masyarakat, loyalitas pelanggan semakin tinggi dan tercipta rekomendasi dari mulut ke mulut yang menguntungkan bagi usaha jasa salon. 
Hasil pengamatan peneliti di Skin Origin, terlihat adanya korelasi yang cukup signifikan dari upaya pemilik salon dalam meningkatkan kualitas layanan jasa dengan beragam pilihan produksi jasa yang diberikan pada pelanggan setiap harinya. Berdasarkan informasi yang diperoleh dari pemilik Skin Origin, diketahui rata-rata pengunjung perharinya adalah 15 orang. Jumlah tersebut bisa bertambah pada saat-saat tertentu dimana salon ramai dikunjungi. Misalnya pada hari-hari besar nasional, hari raya, tahun baru, ataupun beberapa hari sebelum pelanggan mengadakan acara pesta pernikahan.

Parasuraman (2002:499) menyatakan bahwa ada lima dimensi kualitas pelayanan, yaitu: Reliability (Keandalan atau kemampuan dalam mewujudkan janji), Responsiveness (Ketanggapan dalam memberikan pelayanan), Assurance (Keyakinan atau kemampuan memberikan jaminan pelayanan), Emphaty (Memahami keinginan konsumen), dan Tangibles (Tampilan fisik pelayanan). Contoh dari dimensi reliability pada Skin Origin adalah, seorang beautician (ahli kecantikan) harus benar-benar memahami dimensi ini, karena dengan memahami dimensi reliability seorang beautician (ahli kecantikan) dapat mengukur dirinya dalam melakukan tindakan perawatan seperti apa yang akan diberikan kepada pelanggan. Pada dimensi responsiveness (ketanggapan dalam memberikan pelayanan) sangat penting dimiliki oleh semua pekerja jasa, dalam Skin Origin seorang beautician wajib memiliki sifat yang tanggap dan mampu memberikan pelayanan yang terbaik untuk pelanggan maka pelanggan akan merasa nyaman dan tidak ragu untuk datang kembali untuk melakukan repurchase intention (pembelian ulang), sedangkan untuk dimensi tangibles (tampilan fisik pelayanan) juga penting diterapkan pada penjualan jasa bidang tata kecantikan, pada perusahaan Skin Origin seorang beautician harus mampu berpenampilan rapi dan bersih agar calon pelanggan akan merasa yakin dengan pelayanan yang akan diberikan.

Dimensi-dimensi inilah yang harus diperhatikan oleh para beautician ataupun perusahaan salon kecantikan dalam bisnis mereka sehingga pelanggan akan merasa puas. Tidak sedikit pelanggan beralih ke tempat/jasa yang lainnya karena merasa tidak puas dan tidak sesuai dengan harapan mereka pada saat melakukan perawatan. Apabila hal seperti ini terjadi tentunya perusahaan akan berdampak kerugian bagi perusahaan, dengan mengingat untuk mendapatkan pelanggan yang baru lebih besar biayanya dibandingkan dengan pengorbanan dalam mempertahankan pelanggan yang lama. Sejauh apa pentingnya pelayanan dalam suatu perusahaan untuk menciptakan kepuasan yang maksimal harus dijadikan prioritas utama dalam perusahaan.

\section{KAJIAN LITERATUR DAN KERANGKA PEMIKIRAN}

Zeithaml dkk (dalam Hardiansyah 2011:46) mengatakan bahwa untuk dapat mengetahui kualitas pelayanan yang dirasakan secara nyata oleh konsumen, terletak pada lima dimensi kualitas pelayanan, yaitu: reliability, responsiveness, assurance, emphaty, dan tangible. Tjiptono (dalam Aditya, 2011:23) mengatakan bahwa, kualitas jasa merupakan sesuatu yang dipersepsikan oleh pelanggan. Pelanggan menilai kualitas sebuah jasa yang dirasakan berdasarkan apa yang dideskripsikan dalam benak mereka. Pelanggan akan beralih ke penyedia jasa lain yang lebih mampu memahami kebutuhan spesifik pelanggan dan memberikan layanan yang lebih baik.

Faktor utama yang mempengaruhi minat seseorang untuk melakukan repurchase intention yaitu: pribadi, sosial, dan psikologis. Faktor-faktor tersebut memiliki unsur-unsur yang lebih kecil yang membentuk suatu kesatuan tentang bagaimana manusia berperilaku dalam kehidupannya. Contohnya dalam pada faktor pribadi; usia, pekerjaan, dan keadaan ekonomi menentukan minat seseorang dalam melakukan pembelian kembali. Pada faktor psikologis; motivasi, persepsi, dan pembelajaran. Dan pada faktor sosial; budaya, kebiasaan, lingkungan, dan ekonomi juga ikut mempengaruhi. (Kotler \& Keller 2007).

Indikator keputusan pembelian dalam penelitian ini menurut Lamb, dkk, (2001:189) adalah: 1) Pengenalan akan kebutuhan, dimana terjadi ketika konsumen menghadapi ketidakseimbangan antara kebutuhan dan keinginan. 2) Pencarian informasi, dimana setelah mengenali kebutuhan atau keinginan, kosumen akan mencari informasi untuk memastikan kebutuhannya. 3) Evaluasi produk dan alternatif, pada tahap ini konsumen akan menggunakan informasi dimana menurut konsumen bahwa produk yang akan dibeli adalah benar-benar produk yang dibutuhkan. 4) Proses pembelian, sejalan dengan sejumlah alternatif-alternatif yang dipikirkan sebelumnya, maka konsumen akan memutuskan 
produk apa yang akan dibeli. 5) Perilaku setelah pembelian, dimana konsumen mengharapkan bahwa ada dampak tertentu dari pembelian tersebut.

Kepuasan konsumen adalah perasaan senang atau kecewa seseorang muncul setelah membandingkan kinerja produk yang dipikirkan terhadap kinerja yang diharapkan. (Kotler \& Keller 2007:177) Memuaskan keinginan konsumen adalah faktor penting dimana setiap perusahaan harus memahami kebutuhan dan keinginan konsumen demi keberlangsungan hidup perusahaan, dan juga dapat meningkatkan keunggulan perusahaan dari para pesaing. Jika konsumen merasa puas atas pelayanan yang diberikan, maka akan ada peluang untuk datang membeli kembali jasa atau produk dikemudian hari. Hal tersebut menandakan bahwa dengan memiliki kualitas pelayanan yang baik maka akan tercipta kepuasan pelanggan yang baik pula dan kepuasan pelanggan tersebut yang dapat menjadi kunci terbesar terhadap tingkat penjualan perusahaan. Sugiarto (dalam Lupiyoadi, 2010) mengatakan dengan adanya pelayanan yang baik, maka akan menciptakan loyalitas yang erat dan pelanggan tidak berpaling perusahaan lain yang sejenis. Hal ini merupakan wujud dari kesetiaan yang ditunjukan konsumen kepada perusahaan sebagai bukti atas kepuasan yang dirasakan dan atas kinerja produk yang baik.

Peranan sebuah kualitas dari suatu produk atau jasa sangat penting bagi sebuah kelangsungan hidup perusahaan. Kualitas produk barang atau jasa sangatlah penting untuk dapat memuaskan keinginan dan kebutuhan konsumen. Ketika sebuah produk atau jasa yang dikonsumsi konsumen tidak dapat memuaskan konsumen, maka lama-kelamaan konsumen akan beralih pada produk dan jasa lain yang lebih baik. Itulah sebabnya mengapa kualitas sangat penting dalam penciptaan suatu produk atau jasa.

Pelanggan akan menilai bagus atau tidaknya kualitas sebuah jasa atau produk dari hasil pengalaman pribadinya, dan apa yang dirasakan akan mendeskripsikan bagaimana produk tersebut dimata pelanggan. Jika penyedia jasa atau produk tidak mampu memenuhi kebutuhan pelanggan, maka pelanggan akan beralih ke tempat lainnya yang lebih mampu memahami kebutuhan spesifik pelanggan dan memberikan pelayanan yang lebih baik. Persepsi pelanggan terhadap kualitas layanan dapat diukur melalui dimensi kualitas layanan yang dinyatakan oleh Zeithaml, dkk (2009) yaitu: tangibles (tampilan fisik), reliability (keandalan), responsiveness (daya tanggap), assurance (jaminan), dan emphaty (kepedulian).

Skin Origin merupakan salah satu salon kecantikan yang menerapkan pelayanan jasa yang terbaik pada setiap pelanggannya. Skin Origin menyediakan berbagai macam perawatan mulai dari perawatan kulit, wajah, badan, hingga perawatan rambut, dengan tujuan setiap pelanggan dapat memilih jenis perawatan yang diinginkan dan sesuai kebutuhan pelanggan, dengan begitu pelanggan akan merasa puas. Bila pelanggan merasa sudah puas pada purchase yang pertama, maka purchase berikutnya cenderung akan dilakukan secara berulang pada satu merek, sehingga pengambilan keputusan tidak lagi diperlukan karena pelanggan telah mengetahui secara mendalam mengenai merek tersebut (Tatik 2008:15), sehingga dapat dikatakan bahwa pembelian ulang adalah suatu tindakan membeli kembali setelah merasa puas atas pembelian pertama. Berdasarkan logika dari hasil penelitian yang dikemukakan, maka dapat disusun kerangka konseptual penelitian yang tergambar sebagai berikut:

\section{METODE PENELITIAN}

Penelitian ini merupakan penelitian deskriptif-kausal yang memiliki tujuan utama untuk membuktikan hubungan sebab akibat atau hubungan mempengaruhi dan dipengaruhi dari variabel yang diteliti. Variabel penelitian ini yaitu pengaruh variabel independent $(\mathrm{X})$, terhadap variabel dependent (Y), dan dimediasi oleh variabel (Z). Subjek dalam penelitian ini merupakan masyarakat Kota Palu dengan pertimbangan yang telah melakukan pembelian atau perawatan di Skin Origin. Lokasi penelitian dilakukan di wilayah Kota Palu dengan cara membagikan kuisioner.

Populasi dalam penelitian ini adalah seluruh pelanggan yang pernah melakukan perawatan ataupun pembelian lebih dari sekali di Skin Origin, dengan jumlah yang tidak diketahui. Ukuran sampel merujuk pada teori Roscoe dalam Sugiyono (2014:130) dimana penelitian yang akan melakukan Multivarite, maka jumlah sampel minimal 10 kali dari jumlah variabel yang diteliti.

Variabel dalam penelitian ini berjumlah tiga variabel, dimana terdiri dari service quality sebagai variabel independent, customer satisfaction sebagai variabel mediasi, dan repurchase intention sebagai variabel dependent. Berdasarkan pertimbangan teori penggunaan sampel, maka peneliti menetapkan 
jumlah sampel sebanyak 70 responden. Penelitian ini tidak membagi kuisioner kepada seluruh masyarakat untuk dijadikan sampel, sehingga penarikan sampel yang tepat dengan menggunakan nonprobability sampling. Adapun teknik yang digunakan yaitu purposive sampling yang dimana merupakan penarikan sampel dengan pertimbangan tertentu. Skala yang dipakai dalam penelitian ini yaitu skala Likert, dimana skala ini digunakan untuk mengukur sikap, pendapat maupun persepsi responden terhadap suatu fenomena sosial.

Uji validitas digunakan untuk mengukur sah atau valid tidaknya suatu kuesioner. Syarat minimum untuk dianggap memenuhi syarat adalah $\mathrm{r}=0.3$. Jadi, korelasi antara butir dengan skor total kurang dari 0.3 maka butir dalam instrument tersebut dinyatakan tidak valid. Sebaliknya, bila skor total sama dengan 0.3 atau lebih (paling kecil 0.3) maka instrumen tersebut dinyatakan valid, (Sugiyono, 2014:188). Hasil uji validitas Tabel 1 atas item pertanyaan yang terdapat dalam kuisioner penelitian dengan menggunakan bantuan Program Statistik SPSS Versi 16.0:

Uji reliabilitas adalah alat ukur untuk mengatur suatu kuisioner yang merupakan indikator dari variabel. Suatu kuisioner dikatakan reliabel atau handal jika jawaban seseorang terhadap pertanyaan adalah konsisten atau stabil dari waktu ke waktu. Peneliti mengukur reliabelnya suatu variabel dengan cara melihat Cronbach Alpha > 0.60 (Ghozali, 2007:42). Pengujian tingkat reliabilitas sebuah kuesioner penelitian, dapat dilakukan dengan menggunakan program SPSS Versi 16.0 dengan nilai Cronbach Alpha (e) $>0,60$. Adapun hasil olahan datanya sebagai berikut:

Pada tabel di atas, dapat diketahui bahwa nilai Cronbach's Alpha memenuhi syarat $>0,60$. Maka instrument penelitian (kuisioner) dianggap reliable dan layak untuk dilanjutkan.

\section{HASIL DAN PEMBAHASAN}

Berikut hasil pengolahan data dengan menggunakan bantuan komputer dengan alat analisis Partial Least Square (PLS) dengan bantuan program statistic SmartPLS 3.0. Mahfud (2013), mengatakan bahwa PLS digunakan untuk mengetahui kompleksitas hubungan dari suatu konstruk dan konstruk lain, serta hubungan suatu konstruk dan indikator-indikatornya. PLS didasari dari oleh dua tahap, yaitu tahap pertama melakukan evaluasi model pengukuran atau outer model dan tahap kedua adalah melakukan evaluasi model structural atau inner model. Evaluasi tahap pertama atau outer model berfungsi untuk menentukan spesifikasi hubungan antara konstruk dan indikator-indikatornya.

Tabel 9. Original Sample,T-Statistic dan P-Value

\begin{tabular}{|c|c|c|c|c|c|}
\hline Hipotesis & Pengaruh & $\begin{array}{c}\text { Original } \\
\text { Sample }\end{array}$ & $\begin{array}{c}\boldsymbol{T} \text { - } \\
\text { Statistic }\end{array}$ & P-Values & Hasil \\
\hline $\mathrm{H} 1$ & $\begin{array}{c}\text { Service Quality => } \\
\text { Repurchase Intention }\end{array}$ & 0,304 & 1,680 & 0,095 & $\begin{array}{c}\text { Tidak } \\
\text { diterima }\end{array}$ \\
\hline $\mathrm{H} 2$ & $\begin{array}{c}\text { Service Quality => } \\
\text { Customer Satisfaction }\end{array}$ & 0,575 & 6,231 & 0,000 & Diterima \\
\hline $\mathrm{H} 3$ & $\begin{array}{c}\text { Customer Satisfacaction } \\
\text { => Repurchase Intention }\end{array}$ & 0,410 & 2,834 & 0,005 & Diterima \\
\hline $\mathrm{H} 4$ & $\begin{array}{c}\text { Service Quality => } \\
\text { Customer Satisfaction }=> \\
\text { Repurchase Intention }\end{array}$ & 0,236 & 2,976 & 0,003 & Diterima \\
\hline
\end{tabular}

Sumber: Hasil olahan data penelitian

Berdasarkan hasil pengujian hipotesis yang telah dilakukan, selanjutnya akan dilakukan pembahasan hasil dari pengaruh service quality terhadap repurchase intention melalui customer satisfaction pada Skin Origin di Kota Palu. Hasil penelitian terlihat jelas bahwa hipotesis yang berpengaruh yakni service quality terhadap customer satisfaction dan customer satisfaction berpengaruh positif terhadap repurchase intention. Sedangkan service quality tidak berpengaruh terhadap repurchase intention, namun service quality memiliki pengaruh tidak langsung terhadap repurchase intention melalui customer satisfaction. 


\section{Hipotesis 1 : Service Quality berpengaruh secara signifikan terhadap Repurchase Intention}

Penelitian ini service quality dapat diartikan sebagai kualitas pelayanan suatu perusahaan terhadap pelanggan, memberikan pelayanan yang terbaik, penampilan karyawan yang baik, maupun keterampilan dari setiap petugas/karyawan dalam melayani setiap pelanggan. Terpenuhi atau tidaknya harapan mereka dapat diukur berdasarkan lima aspek dimensi kualitas pelayanan. Kelima dimensi tersebut ialah tangibles, emphaty, reliability, responsiveness, dan assurance.

Service Quality diukur dengan 15 indikator. Indikator dari dimensi tangibles dalam penelitian ini adalah petugas berpenampilan baik, memiliki tempat yang nyaman, dan kemudahan dalam perawatan. Indikator dari dimensi emphaty dalam penelitian ini adalah mendahulukan kepentingan pelanggan, karyawan bersikap ramah, dan menghargai setiap pelanggan. Indikator dari dimensi reliability dalam penelitian ini adalah cermat dalam melayani, standard kualitas layanan yang baik, dan kemampuan yang handal. Indikator dari dimensi responsiveness dalam penelitian ini adalah pelayanan yang cepat, cermat dalam melayani, dan merespon pelanggan dengan baik. Indikator dari dimensi assurance dalam penelitian ini adalah tepat waktu dalam perawatan, percaya pada petugas, dan kepastian biaya perawatan. Indikator dari dimensi customer satisfaction dalam penelitain ini adalah pelayanan yang sesuai dengan harapan, berniat untuk mengunjungi kembali, dan kesediaan merekomendasi, dan yang terakhir indikator dimensi repurchase intention adalah berniat mengunjungi kembali, mencoba produk lain yang ditawarkan, dan tidak ragu untuk merekomendasikan.

Hasil penelitian yang dilakukan pada pelanggan Skin Origin Kota Palu, yakni pada service quality terhadap repurchase intention, dimana Skin Origin merupakan tempat yang nyaman untuk melakukan perawatan yang dominan dipilih oleh responden. Hal tersebut paling dominan dipilih responden karena selama melakukan penelitian di Skin Origin, pemilik Skin Origin maupun karyawan yang ada disana sangat ramah pada setiap pelanggan dan memiliki tempat yang sangat nyaman untuk melakukan perawatan dikarenakan fasilitas yang diberikan juga baik, sehingga setiap pelanggan merasa nyaman jika berada di Skin Origin. Selain itu, Skin Origin juga menawarkan harga member yang cukup murah untuk jangka waktu yang lama sehingga setiap pelanggan yang datang untuk melakukan pembelian ulang akan mendapatkan potongan $10 \%$ disetiap pembelian ulang.

Berdasarkan hasil olah data, diperoleh hasil yang tidak signifikan service quality terhadap repurchase intention di Skin Origin Kota Palu, namun service quality memiliki pengaruh tidak langsung terhadap repurchase intention melalui customer satisfaction. Artinya dalam penelitian ini pelanggan Skin Origin Kota Palu akan melakukan repurchase intention atau pembelian kembali setelah mengalami customer satisfaction pada saat perawatan. Penelitian ini sejalan dengan hasil penelitian Saidani dan Arifin (2012) dengan judul penelitian "Pengaruh Kualitas Produk dan Kualitas Layanan Terhadap Kepuasan Konsumen dan Minat Beli Pada Ranch Market" dengan hasil penelitian adanya pengaruh yang signifikan antara variabel kualitas produk dan kualitas layanan terhadap minat beli tetapi pengaruh ini tidak langsung melainkan melalui mediasi kepuasan konsumen. Hasil penelitian ini juga sejalan dengan penelitian yang dilakukan oleh Phuong \& Trang (2018) yang menyatakan bahwa service quality, system quality, information quality dan customer satisfaction memiliki pengaruh terhadap repurchase intention.

\section{Hipotesis 2 : Service Quality berpengaruh secara signifikan terhadap Customer Satisfaction}

Hasil penelitian yang dilakukan pada pelanggan Skin Origin di Kota Palu, yakni pada service quality terhadap customer satisfaction, dimana kesediaan merekomendasi merupakan indikator yang paling dominan dipilih oleh responden. Seperti yang dijelaskan pada hipotesis pertama bahwa pelayanan yang diberikan oleh Skin Origin sangat baik dan memuaskan maka pelanggan merasa puas atas pelayanan yang diberikan.

Berdasarkan hasil olah data, diperoleh hasil yang signifikan service qualiy terhadap customer satisfaction di Skin Origin Kota Palu. Artinya bahwa semakin tinggi pelayanan yang diberikan oleh Skin Origin maka semakin tinggi pula kepuasan yang dirasakan oleh pelanggan. Sebaliknya, semakin rendah service quality maka semakin rendah pula kepuasan yang didapatkan oleh pelanggan. 
Penelitian ini sejalan dengan hasil penelitian yang dilakukan oleh Saidani dan Arifin (2012), Jonathan (2013), Sativa dan Astuti (2016) yang menyatakan bahwa variabel service quality berpengaruh secara signifikan terhadap customer satisfaction.

\section{Hipotesis 3 : Customer Satisfaction berpengaruh secara signifikan terhadap Repurchase Intention}

Customer satisfaction juga bisa diartikan sebagai kepuasan konsumen mengenai layanan dan terpenuhnya harapan pelanggan terhadap pelayanan yang diberikan sehingga pelanggan datang kembali untuk melakukan repurchase intention. Adapun indikator dalam variabel customer satisfaction yaitu pelayanan sesuai dengan harapan, berniat untuk mengunjungi kembali, dan ketersediaan merekomendasi kepada kerabat.

Penelitian yang dilakukan pada pelanggan Skin Origin di Kota Palu, yakni customer satisfaction dimana niat untuk mencoba produk lain yang ditawarkan oleh Skin Origin merupakan indikator yang dominan yang dipilih oleh responden. Hal ini dikarenakan pelayanan yang diberikan sejauh ini baik, sehingga pelanggan merasa puas lalu pelanggan berniat untuk mencoba produk maupun jenis perawatan lainnya yang ditawarkan oleh Skin Origin.

Berdasarkan uji statistik, diperoleh hasil customer satisfaction berpengaruh terhadap repurchase intention. Hal ini menunjukan bahwa jika pelanggan merasa puas maka pelanggan akan datang kembali untuk melakukan pembelian berikutnya. Artinya bahwa semakin tinggi tingkat kepuasan pelanggan maka semakin tinggi pula peluang pelanggan tersebut akan kembali datang melakukan purchase berikutnya. Sebaliknya, jika semakin rendah customer satisfaction yang dirasakan oleh pelanggan maka semakin rendah pula peluang pelanggan tersebut untuk datang kembali melakukan pembelian berikutnya.

Hal ini sejalan dengan hasil penelitian yang dilakukan oleh Ardhanari (2008), Hong dan Brahmana (2010), Saidani dan Arifin (2012) yang menyatakan bahwa variabel customer satisfaction berpengaruh secara signifikan terhadap repurchase intention.

\section{Hipotesis 4 : Service Quality berpengaruh signifikan terhadap Customer Satisfaction melalui Repurchase Intention}

Berdasarkan uji statistik, diperoleh hasil service quality berpengaruh terhadap repurchase intention melalui customer satisfaction. Hal ini menunjukkan apabila pelanggan merasa puas atas service quality yang diberikan oleh Skin Origin, maka pelanggan akan menjadi loyal pada perusahaan. Sebaliknya, jika pelanggan merasa tidak puas dengan service quality yang diberikan maka akan menghasilkan pelanggan yang tidak loyal.

Suatu perusahaan yang memiliki konsistensi service quality yang baik serta memberikan harapan yang dibutuhkan pelanggan dan mewujudkan harapan yang dibutuhkan konsumen dalam rangka menjaga kepuasan pelanggan maka akan ada peluang untuk memperoleh konsumen yang loyal dan mencapai keuntungan yang besar. Hal ini dapat diperoleh jika perusahaan mampu menjaga standard kualitas yang dimiliki, dan tetap mementingkan kebutuhan setiap pelanggan.

Salon kecantikan yang baik, adalah salon yang memiliki pelayanan yang dapat memuaskan setiap pelanggan. Hal ini yang membuat indikator dari customer satisfaction yaitu pelayanan yang diberikan sesuai dengan harapan pelanggan menjadi dominan, sehingga konsumen akan terus merekomendasikan Skin Origin ke orang lain karena pelayanan yang memuaskan sesuai dengan indikator customer satisfaction yang paling dominan dipilih.

Hal ini sejalan dengan hasil penelitian yang dilakukan oleh Adixio \& Saleh (2013) yang menyatakan bahwa kualitas layanan berpengaruh positif signifikan terhadap niat pembelian ulang melalui mediasi kepuasan pelanggan dapat diterima. Hal ini juga sejalan dengan penelitian Farisya (2012) yang menyatakan bahwa pengalaman dari konsumen setelah melakukan pembelian produk ataupun jasa memiliki pengaruh terhadap repurchase intention dengan diperantarai oleh kepuasan konsumen. 


\section{KESIMPULAN DAN SARAN}

\section{Kesimpulan}

Berdasarkan hasil dan pembahasan penelitian yang mengangkat judul "Pengaruh Service Quality terhadap Repurchase Intention melalui Customer Satisfaction (Studi Pada Skin Origin di Kota Palu)" maka dapat disimpulkan sebagai berikut:

1. Service quality tidak mempengaruhi repurchase intention di salon kecantikan Skin Origin di Kota Palu.

2. Service quality mempengaruhi customer satisfaction di salon kecantikan Skin Origin Kota Palu.

3. Customer satisfaction mempengaruhi repurchase intention di salon kecantikan Skin Origin Kota Palu.

4. Service quality memiliki pengaruh tidak langsung terhadap repurchase intention, tetapi harus melalui customer satisfaction di salon kecantikan Skin Origin Kota Palu.

\section{Saran}

Berdasarkan uraian hasil peneliti dan kesimpulan, maka ada berapa hal yang perlu direkomendasikan kepada pihak-pihak yang terkait dalam penelitian ini sebagai berikut:

1. Skin Origin diharapkan untuk tetap menjaga konsistensi kualitas layanan yang dimiliki agar konsumen tetap merasa puas dengan pelayanan yang diberikan.

2. Petugas/karyawan diharapkan untuk lebih lagi memperhatikan penampilannya dan tetap bersikap baik dan sopan pada semua pelanggan.

3. Skin Origin diharapkan untuk lebih sering memperbarui sosial media agar lebih dikenal lagi.

4. Petugas/karyawan diharapkan untuk lebih cermat lagi dalam melayani pelanggan yang datang untuk melakukan perawatan ataupun sekedar konsultasi.

5. Petugas/karyawan diharapkan untuk memberikan jaminan tepat waktu dalam melakukan perawatan.

\section{REFERENSI}

Adixio, R. F., \& Saleh, L. (2013). Pengaruh Kualitas Layanan dan Nilai yang Dirasakan Terhadap Niat Pembelian Ulang Melalui Mediasi Kepuasan Pelanggan Restoran Solaria di Surabaya. Journal of Business and Banking.

Ardhanari, M. (2008). Costumer Satisfaction Pengaruhnya Terhadap Brand Preference Dan Repurchase Intention Private Brand. Jurnal Riset Ekonomi dan Bisnis.

Aditya, Tjiptjono, 2011, Pengaruh Kualitas Pelayanan dan Kualitas Produk Terhadap Keputusan Pembelian. 2011:23

Farisya (2012). Pengaruh Experiental Marketing Terhadap Repurchase Intention Melalui Customer Satisfaction Sebagai Invervening Variabel (Studi Pada: Nany's Pavillion Bathroom - Pasific Place).

Ghozali, Imam .(2007). Aplikasi Analisis Multivariate dengan Program IBM SPSS 23. Semarang: Badan Penerbit Universitas Diponegoro.

Ghozali, Latan (2015). Prinsip Alat Ukur Convergent Validity Outer Loading.

Hardiansyah. 2011. Kualitas Pelayanan Publik. Yogyakarta: Gava Media.

Hong, B., \& Brahmana, R. K. (2010.). Pengaruh Service Quality, Perceived Value, Costumer Satisfaction terhadap Repurchase Intention Pelanggan di Resto Buro Bar Surabaya.

Iin. (2013, Januari 21). champiet: Manajemen Jasa. Schoell dan Gultinan mengatakan berbagai faktor bisa dikemukakan sebagai pemicu perkembangan sektor jasa yang demikian maju pesat. diambil dari website: http://iincimoetz.blogspot.com/2013/01/manajemen-jasa_21.html

Jonathan (2013). Analisis Pengaruh E-Service Quality Terhadap Customer Satisfaction Yang Berdampak Pada Customer Loyality PT Bayu Buana Travel TBK.

Kotler, Philip Dan Kevin Lane Keller. (2007). Manajemen Pemasaran. Edisi Kedua Belas. Indeks : Jakarta

Kotler, Philip. \& Gary Armstrong. 2016. Prinsip-Prinsip Pemasaran. Edisi 13 Jilid 1. Jakarta: Erlangga.m

Lamb, Charles W. dkk 2001. Pemasaran Bisnis. Penerbit Salemba Empat, Jakarta. 
Vol. 6, No.2, Mei 2020, 177-185

Lupiyoadi, Rambat (2010). Manajemen Pemasaran Jasa, Jakarta: Salemba Empat

Mahfud, Sholihin \& DwiRatmono. (2013). Analisis SEM-PLS Dengan Warppls 3.0 Untuk Hubungan Non Linier Dalam Penelitian Sosial dan Bisnis. Andi Yogyakarta.

Parasuraman, A. (2002), "Service Quality and productivityy: a synergistic perspective", Managing Service: An International Journal, Vol. 12 No.1, pp. 6-9.

Phuong, \& Trang. (2018). Repurchase Intention: The effecr of service quality, system quality, information quality, and costumer satisfaction as mediating role: A PLS Approach of MCommerce Ride Hailing Service in Vietnam. AIMI Journals, 78-91.

Saidani, B., \& Arifin, S. (2012). Pengaruh Kualitas Produk dan Kualitas Layanan Terhadap Kepuasan Konsumen dan Minat Beli Pada Ranch Market. Jurnal Riset Manajemen Sains Indonesia.

Sativa, A. \& Astuti (2016). Analisis Pengaruh E-Trust dan E-Service Quality Terhadap E-Loyality dengan E-Satisfaction sebagai Variabel Itervening (Studi Pada Pengguna E-Commerce C2C Tokopedia). Diponegoro Journal Of Management. Vol 5, No.3. Hal 1-10.

Sugiyono. (2014). Metode Penelitian Kuantitatif dan R\&D. Bandung: CV Alfabeta.

Tatik, Suryani (2008). Perilaku Konsumen: Implikasi pada Strategi Pemasaran. Yogyakarta: Graha Ilmu.

Zeithaml, V.A., Bitner, M. J., \& Gremier, D. D.(2009).ServiceMarketing Mix. New York: Mc Graw Hill. 